\title{
Viktor Blåsjö
}

ORCID $\underline{\text { 0000-0001-8494-4567 }}$

Mathematical Institute, Utrecht University (Utrecht, The Netherlands)

V.N.E.Blasjo@uu.nl

\section{A rebuttal of recent arguments for Maragha influence on Copernicus}

\begin{abstract}
I reply to recent arguments by Peter Barker \& Tofigh Heidarzadeh, Arun Bala, and F. Jamil Ragep claiming that certain aspects Copernicus's astronomical models where influenced by late Islamic authors connected with the Maragha school. In particular, I argue that: the deleted passage in De revolutionibus that allegedly references unspecified previous authors on the Tusi couple actually refers to a simple harmonic motion, and not the Tusi couple; the arguments based on lettering and other conventions used in Copernicus's figure for the Tusi couple have no evidentiary merit whatever; alleged indications that Nicole Oresme was aware of the Tusi couple are much more naturally explained on other grounds; plausibility considerations regarding the status of
\end{abstract}

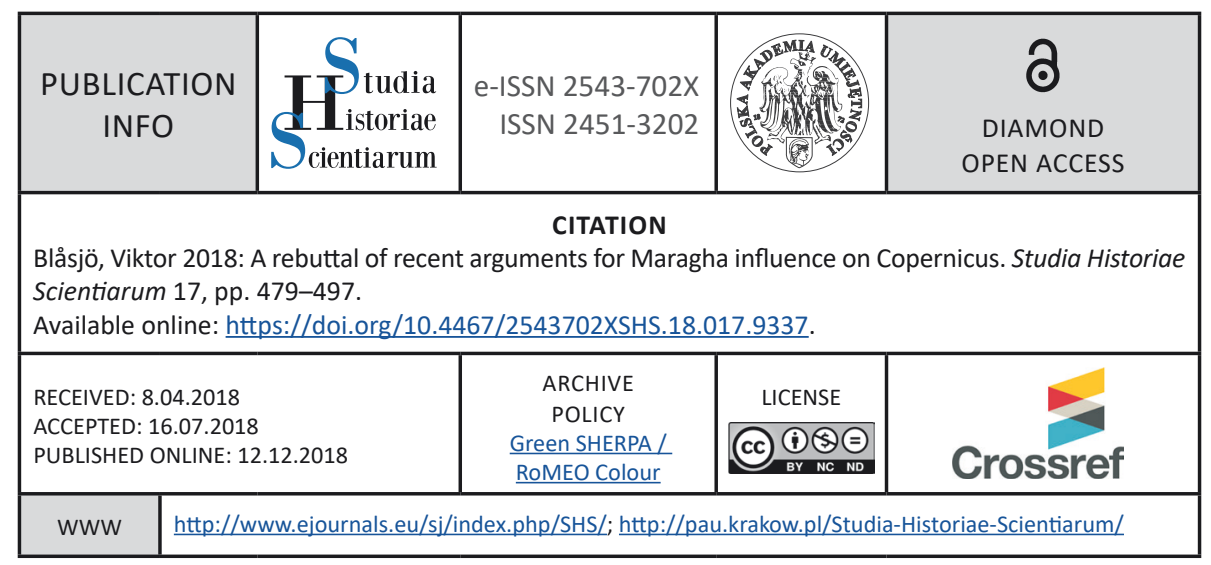


Arabic astronomy and norms regarding novelty claims weight against the influence thesis, not for it.

Keywords: Copernicus, Maragha school, Tusi couple, harmonic motion.

\title{
Obalenie ostatnio głoszonych argumentów za wpływem szkoły z Maragha na Kopernika
}

\begin{abstract}
Odpowiadam na ostatnie argumenty Petera Barkera i Tofigh Heidarzadeha, Aruna Bali i F. Jamila Ragepa, wedle których na pewne aspekty modeli astronomicznych Kopernika wywarli wpływ późni islamscy autorzy związani ze szkołą w Maragha. W szczególności argumentuję, że: skreślony fragment De revolutionibus, który rzekomo odnosi się do bliżej nieokreślonych poprzednich autorów analizujących mechanizm Tusiego, faktycznie odnosi się do prostego ruchu harmonicznego; argumenty oparte na symbolach literowych i innych konwencjach wykresu Kopernika dla mechanizmu Tusiego nie mają żadnej wartości dowodowej; domniemane oznaki, że Nicole Oresme był świadomy istnienia mechanizmu Tusiego, są znacznie bardziej naturalnie wyjaśnione na innych podstawach; względy dotyczące wiarygodności statusu arabskiej astronomii i normy dotyczące idei nowatorstwa w nauce przemawiaja przeciwko tezie o wpływie na Kopernika islamskich autorów związanych ze szkoła w Maragha.
\end{abstract}

Słowa kluczowe: Kopernik, Maragha school, mechanizm Tusiego, ruch harmoniczny.

\section{Introduction}

In certain mathematical details, Copernicus's astronomical models are similar to those of late medieval Arabic astronomers associated with the Maragha school. Some historians have felt that Copernicus must have been aware of these earlier sources and taken over key ideas from them, though there is no direct evidence for such transmission or influence. In Blåsjö 2014, I challenged this thesis. I argued that independent discovery by Copernicus is perfectly plausible. I went through all 
specific arguments proposed in the literature as evidence of Copernicus's indebtedness to the Maragha school and offered a point-by-point rebuttal case against them. My work complements more comprehensive studies of Copernicus that have shown how the thesis of independent discovery by Copernicus is consistent with a holistic and contextually sensitive picture of his works (Kokowski 2004, Goddu 2010, Copernic 2015).

Since my paper appeared, Barker \& Heidarzadeh 2016, Bala 2016, and Ragep 2017 have reaffirmed the influence thesis and tried to counter my arguments. In this paper I reply to their replies. Since Ragep 2017, p. 267, has labelled me a "transmission sceptic," it seems natural for me to refer to these authors collectively as "transmission believers." Let me point out that it is also instructive to note which of my arguments have not been countered. This includes my refutation of the argument based on Copernicus's alleged misunderstanding of an aspect of his Mercury model in the Commentariolus. Swerdlow, the originator of the argument, called this "perhaps the best evidence" of Maragha influence on Copernicus (Swerdlow 1973, p. 504), and many have agreed that it "elevates the discussion of the similarities to a whole new level" (Saliba 2007 , p. 207). This argument was definitively refuted in my paper. Although Swerdlow has since reaffirmed his belief in "Copernicus's undoubted debt to the planetary and lunar theory of Ibn ash-Shātir and ... his reliance upon Marāgha astronomy" (Swerdlow 2017, p. 34), one can rest assured that Swerdlow would not have missed the opportunity to refute my critique of his Mercury argument if there were any grounds for doing so.

\section{Copernicus's deleted "aliqui"}

One notable mathematical technique shared by Copernicus and the Maragha astronomers is the Tusi couple (Figure 1) - a device that generates rectilinear motion from a combination of circular motions. As argued in Blåsjö 2014, it would not be surprising for such a simple idea to have been independently discovered a number of times by astronomers and geometers, so the mere fact that Copernicus used it does not prove anything about transmission. However, transmission believers maintain that in a manuscript discussing this device Copernicus made an oblique reference to the late Islamic astronomical tradition: 
In a tantalizing passage deleted from the printed version of De revolutionibus, Copernicus makes it clear that he is not the first person to use the Tusi device, saying, "Some people call this 'the motion along the width of the circle', that is, along the diameter" (Barker \& Heidarzadeh 2016, p. 42).

Copernicus himself mentions "some people" who refer to the Tusi device as producing "motion along the width of a circle" (Ragep 2017, p. 185).

The passage in question reads:

Accordingly some people call this the "motion along the width of a circle," that is, along the diameter. Yet they treat its period and uniformity in terms of the circumference, but its magnitude in terms of chords. Hence it appears nonuniform, faster around the center and slower near the circumference. $^{1}$

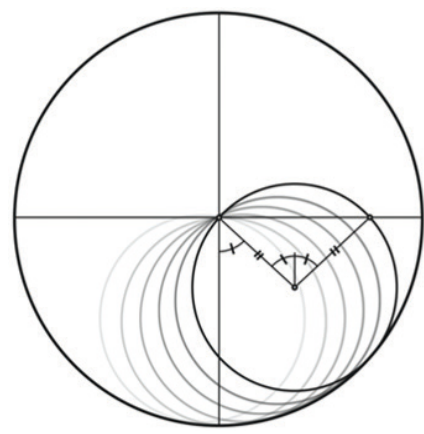

Figure 1. The Tusi couple. As the large circle rotates counterclockwise, the small circle rotates clockwise with twice the speed. A fixed point on the small circle then moves rectilinearly along a diameter of the large circle.

${ }^{1}$ Dobrzycki \& Rosen 1978, p. 126. The Latin is: "Eam ob causam vocant aliqui motum hunc circuli in latitudinem, hoc est in diametrum, cuius tamen periodum et aequalitatem in circumcurrente, at dimensionem in subtensis lineis accipiunt" (Nobis \& Sticker 1984, p. 152). This is from De Revolutionibus III.5, except the final published version differs slightly from this manuscript version. The actually printed version has "vocare possumus" (we can say) in place of "vocant aliqui" (some say) and, in keeping with this, "accipimus" in place of "accipiunt." 
This passage follows almost immediately after Copernicus's detailed description of the Tusi couple. However, there is one important paragraph in between. After proving that the Tusi couple produces rectilinear motion, Copernicus goes on to note more exactly the nature of the motion along this line. He specifies it in terms of chords and arcs: in modern terms we can express his remark in the equation $x=\cos (t)$, where $x$ is the position of the point along the line, and $t$ is the angle of the radial arm of the main circular motion, which, since the circular motion is uniform, is equivalent to time. This kind of rectilinear motion is nowadays called simple harmonic motion. It can also be characterised as the perpendicular projection of a point moving uniformly in a circle onto the diameter of that circle.

I say that the "this" in Copernicus's remark is not the Tusi couple, but harmonic motion. Copernicus is not saying that others before him have used the Tusi couple and given its motion a special name. Rather he is saying that the kind of rectilinear motion that the Tusi couple produces is already known and has a name. But this is a separate point from the fact that such motion can be generated by the Tusi couple, which Copernicus gives no indication that the "some" people in question knew anything about.

This reading fits much better with the rest of Copernicus's paragraph. When describing harmonic motion we indeed "treat its period and uniformity in terms of the circumference" yet characterise "its magnitude in terms of chords": that is, we describe its position along a linear axis in terms of sines or cosines, but express its periodicity and speed most easily in terms of the underlying circular motion. This is exactly what a cosine function does: it translates circular motion into its corresponding horizontal motion, that is to say, motion along the width or diameter of a circle. Obviously this motion is indeed "faster around the center and slower near the circumference."

My interpretation is also confirmed by the account given by Rheticus, who would certainly have known exactly what his master Copernicus meant. He writes in the Narratio Prima:

While thus describing a straight line through the combination of two circular motions, the point $b$ moves most slowly near the ends $a$ and $b$, and more rapidly near the center d. It has therefore pleased my teacher to name this motion 
of the point $\mathrm{h}$ along the line $a b$ a "libration," because it resembles the motion of objects hanging in the air. It is also called motion along the diameter; for if you imagine a circle with diameter $a b$ and center $d$, the position on the diameter $a b$, to which the point $b$ is brought by the aforesaid combined motion of the small circles, is determined from the doctrine of chords (Rosen 1939, pp. 154-155).

Again, "motion in diameter" clearly refers to harmonic motion, not the Tusi couple. It is indeed "determined from the doctrine of chords" - that is, given by a cosine function. The comparison with "objects hanging in the air" is a very apt one: it is seemingly a reference to the bobbing up-and-down motion of a weight suspended in the air by means of an elastic band or a spring, which is indeed the paradigm example of simple harmonic motion still used in all physics textbooks today. Alternatively, Rheticus's phrase could possibly be an allusion to pendulum motion, which is also approximately harmonic and again a staple example used in modern textbooks on this subject.

In all, simple harmonic motion is a very basic concept that arises naturally in many contexts that have nothing to do with the Tusi couple: it is the projection onto an axis of uniform circular motion; it is in effect inherent in any trigonometric table, since it is given by a sine or cosine table by simply reading the arc or angle as time and the sine or cosine as position; and it describes basic natural phenomena such as weights on springs and pendulums. Copernicus's passage can therefore not be read as saying that others have studied the Tusi couple. More literally it says only that others have studied and named simple harmonic motion, which they could very plausibly have done completely independently of the Tusi couple.

\section{Claims to novelty}

Transmission believers have seized on the fact that Copernicus did not explicitly state that the Tusi couple was his own discovery. "It would be quite unusual for someone who invented as significant a device as the Tusi-couple not to claim it as his own," they maintain. I disagree. It is

\footnotetext{
${ }^{2}$ Ragep 2017, p. 271. A very similar argument is made by Bala 2016, p. 73.
} 
unreasonable to expect a mathematician to expressly point out that each of his theorems are his own. How many mathematical treatises have you read where, in the middle of the mathematical exposition, the author chimes in and says "I discovered this myself"? If this is a required mark of originality we would have to infer that many other great mathematicians never made a single discovery, because such remarks are generally lacking in their works too.

Assertions of this kind ... in which an author expressly claims a proposition or device to be his own ... are indeed very seldom in Antiquity and in the Middle Ages; I believe the contrary happens much more frequently, viz., that an author ascribes a new invention of his to an authority of the past. ${ }^{3}$

Indeed, Copernicus does bring up ancient authority in this connection. ${ }^{4}$ But even this point aside there are grounds to question Ragep's claim that

no one after Tusi claims to have independently discovered any of the versions of the couple, either in the Islamic world or in the Latin West. ${ }^{5}$

There are in fact some claims to discovery in Latin sources. Nicholaus Müller, in his commentary to the 1617 edition of De revolutionibus, explicitly states that the Tusi couple was invented by Copernicus. ${ }^{6}$ Cardano, in a work from 1570, discusses the Tusi couple and attributes its discovery to Ferrari. ${ }^{7}$ Of course Müller and Cardano may be wrong. It is possible that they were unaware of earlier sources that had served as inspiration. Even so, these passages problematise Ragep's claim, and

${ }^{3}$ Hartner 1971, p. 631.

${ }^{4}$ Referring to Proclus regarding the possibility of producing rectilinear motion from circular motion. De revolutionibus, V.25. Veselovsky 1973; Di Bono 1995, p. 146.

${ }^{5}$ Ragep 2017, p. 196.

6 "Commentum est Copernici" (Nobis \& Pastori 2002, p. 385). This was noted by Curtze 1895 , p. 34.

7 Cardano, Opera omnia, IV.561. "Hoc inventum fuit Ludovici Ferrarij." Also noted by Curtze 1895, p. 34, who believes independent discoveries to be the most plausible explanation. 
certainly undermine his suggestion that Copernicus could "without qualms" cross out the remark about others who had spoken about the rectilinear motion since the Tusi couple "had become commonplace" in the Latin West at this time. ${ }^{8}$

\section{Lettering and orientation of diagrams}

A longstanding argument in the literature holds that the labelling of points in the diagram for the Tusi couple used by Tusi and Copernicus are strikingly similar in a way that is highly unlikely to have occurred by chance. In Blåsjö 2014, I refuted this argument. The simple fact of the matter is: In Copernicus's figure the lettering is exactly the alphabetical order following the order in which the points occur in the proof, just as in every proposition of Euclid and other geometrical treatises. So his lettering is the obvious and natural one, and there are no grounds whatsoever for trying to argue that there is some kind of remarkable or unexplained coincidence involved here.

Barker \& Heidarzadeh spend much time trying to resurrect the lettering argument, but their efforts are misguided because they have not taken into account the obvious fact that the lettering of mathematical diagrams generally follow a natural numerical/alphabetical ordering corresponding to the order in which the points occur in the proof. All of Barker \& Heidarzadeh's arguments are based on ignoring this convention. Thus:

Blåsjö, Goddu and Di Bono have denied any correspondence here, on the grounds that the choices of lettering are to be expected given conventions in the Islamic and Latin mathematical communities. As an initial way to evaluate their claim, let us compare Copernicus' diagram with the next three versions to appear in Europe. ... Suppose we represent the positions of the letters in the order used by Copernicus as 12345678 . The 1568 version is then 12435867. Magini's from 1589 will be 41352687 and Maestlin's version from 1596 will be 12435687 . From these examples, we are unable to identify any convention plausibly

\footnotetext{
${ }^{8}$ Ragep 2017, p. 197.
} 
shared by all of these authors, beyond the use of letters from the beginning of the alphabet (Barker \& Heidarzadeh 2016, pp. 37-38).

This is nonsense in light of the alphabetical convention. First of all it is absurd to look only at the diagrams in isolation, as Barker \& Heidarzadeh do, since the alphabetical convention pertains to the proofs. But let us say for the sake of argument that some examples like these can be found that violate the alphabetical convention. Would this prove anything? Of course not. No one has claimed that the alphabetical convention is absolutely universal. Of course sometimes mathematicians deviate from the alphabetical convention, for instance because of later revisions or alterations of an original draft, or for the sake of agreement with other figures in the same work. Nevertheless it is an undeniable fact that the alphabetical convention is extremely well entrenched in the mathematical literature. It is therefore absurd to characterise a figure that follows it perfectly - as Copernicus's does - as in any way exceptional.

Barker \& Heidarzadeh also appeal to other diagrammatic similarities to revive the case for Tusi couple transmission. Thus:

[In Tusi and Copernicus,] the orientation of the outer circles and their radii are the same, which is curious if the two authors were drawing figures independently (Barker \& Heidarzadeh 2016, p. 23).

I say: no, it is not "curious" because they are simply following Ptolemaic tradition. For instance, the epicycle is in the top left quadrant, which also seems to be the quadrant favoured by Ptolemy for showing epicycles in general position (as when he introduces them [Toomer 1998, Figures 3.5, 3.6], and most times after that). Barker \& Heidarzadeh continue:

And the senses of rotation of the major circles are the same. ... The large circle rotates counterclockwise. ... But the same results would follow by reversing the directions of rotations, leading to an alternative diagram. ... So Tusi's proof embodies a choice about which direction everything should move. ... This choice is perhaps influenced by the convention of reading Arabic script from right to left (Barker \& Heidarzadeh 2016, pp. 23, 28). 
But the large circle rotates counterclockwise in Ptolemy's basic epicycle model as well. And this is no arbitrary choice: it corresponds to the natural convention that one is viewing the universe "from above" (i.e., from above the earth's north pole). This is a more plausible explanation than the direction of Arabic script. So this is not an "unexplained coincidence" (Barker \& Heidarzadeh 2016, p. 29) but simply the default expectation.

In sum, there is absolutely nothing about Copernicus's diagram that is even the least bit unusual, let alone anything that would "require a gross violation of probabilities" (Barker \& Heidarzadeh 2016, p. 54) for him to have come up with. On the contrary, Copernicus is simply following standard conventions. Everything about his diagram is exactly as would be expected if he simply followed Ptolemy on how to draw epicycles and Euclid and every other mathematician in how to label points. The same can be said for Tusi, to a large extent, so there is no wonder that there are many agreements between them.

\section{Oresme and the Tusi couple}

Oresme once argued that "it is possible for some planet to be moved perpetually in a rectilinear motion composed of several circular motions." This is reminiscent of a Tusi couple. Did Oresme somehow get the idea through some form of transmission from Tusi's work, where it had been described a century before? Ragep and Kren believe so. To support their view they offer imaginative interpretations of Oresme's text. Oresme's description of this matter is very vague and incomplete, as everyone agrees. One might consider this a natural consequence of it being a half-baked idea in a qualitative Aristotelian treatise, but Ragep and Kren instead seek to diagnose these shortcomings as stemming from misunderstandings of Tusi's original model. Thus Kren suggests that Oresme came across "some possibly fragmentary and even garbled version of the al-Tusi device" and that "behind the fragmentary incoherence of the passage from Oresme there may lie an attempt to describe" Tusi's original device (Kren 1971, pp. 497, 494). Ragep (2017,

${ }^{9}$ Droppers 1966, p. 285; Kren 1971, p. 490; Ragep 2017, p. 177. Droppers 1966 contains the full Latin treatise and a complete English translation. 
p. 181), offers a variant interpretation in a similar spirit. For him too it is precisely the vagueness and confusion of Oresme's text that supposedly proves that he must be copying ideas from the Arabic tradition: "given [Oresme's] apparent lack of understanding of the necessity of having the epicycle move at twice the speed of the deferent, it would be implausible in the extreme to assume that he reinvented this model."

In my view, there is a much simpler and more straightforward way to make sense of Oresme's passage, which does not rely on postulating that Oresme somehow got the idea from a treatise which there is virtually no evidence that anyone within hundreds of miles and hundreds of years of Oresme even knew existed, let alone understood, and also does not rely on postulating that the idea of the Tusi couple was somehow "garbled" in transmission even though it is simple and crystal clear in the original. Instead I see Oresme as making a rather trifling geometrical observation, which is very much in step with his non-technical approach to astronomical questions generally.

My reading of Oresme is as follows. Consider a simple epicycle setup, with the radii being whatever, and with the deferent and the epicycle rotating in opposite directions. Let the initial configuration of the diagram be such that the planet is located on the horizontal line through the center of the deferent. Now as the deferent rotates it will move the planet upwards, say. Then let the epicycle rotate by whatever amount necessary to cancel this upward motion with an equal downward motion, so that, vertically, the planet remains on the same horizontal line. The planet will also have some sideways motion but we don't care about that. In the next interval of time we again make the epicycle precisely cancel whatever vertical motion the deferent imparts on the planet. This is how we define the motion of the epicycle. If the epicycle is big enough to always intersect the horizontal line, we can keep the planet on this line indefinitely. Of course this means there is no reason to think that the epicycle is rotating uniformly. And indeed Oresme himself explicitly recognises the objection that "it is impossible for a planet to be moved in this way, if such circular motions are regular."

On this reading, Oresme's idea is an unremarkable one, which he could easily have thought of himself. It is a much more elementary idea than a mathematical understanding of the principle of the Tusi couple.

Kren argues in some detail that "what we know of Nicole Oresme's particular predilections would have made it likely that an account of 
the device would have caught his attention," since it fits naturally with his documented interest in the nature of celestial motions (Kren 1971, p. 497). This is true, but the most natural way to view this is not as an argument for transmission, but rather as evidence that Oresme had every reason and occasion in the world to discover his trifling idea himself in the natural course of his own work.

In keeping with the argument we discussed in Section 3, Ragep (2017, p. 181), raises the point that "Oresme makes no claim to have invented this model on his own." This is a baffling assertion since Oresme does in fact say "I propose" (pono) right at the beginning of his discussion of this exact point.

\section{The role of Arabic sources in early modern astronomy}

Ragep thinks independent discovery by Copernicus of the techniques he has in common with Islamic authors is implausible because:

Perhaps most importantly, why would someone seek to start from scratch when it was certainly known in the fifteenth and sixteenth centuries that Islamic astronomers still had much to teach their European counterparts? (Ragep 2017, p. 194) ${ }^{10}$

Did European astronomers at the time really consider Islamic astronomers much more advanced than themselves? There is no evidence that Copernicus ever held such an opinion, and very little or no evidence that any of his contemporary colleagues did either. Indeed, Ragep does not support his claim with any actual evidence from this century at all. Instead he adduces a footnote that says: "This was even the case in the early seventeenth century," in support of which he cites Feingold 1996. Ragep's logic seems to be that if Arabic sources "still had much to teach Europeans" in the 17th century, then, a fortiori, they did so also in 1500 , even if we have no direct evidence from this period.

In fact, the evidence that Ragep himself choses to bring up actually proves the opposite of his point. Here is what Feingold has to say:

${ }^{10}$ Barker \& Heidarzadeh (2016, p. 55), make the same point. Like Ragep, they offer virtually no evidence for their claim, only two citations pertaining to astrolabes and instruments that are completely immaterial to the issues Copernicus was concerned with. 
Most of those who sought access to Arabic science were animated by "reductionist" motives: They viewed "the achievement of Islamic scientists merely [as] a reflection, sometimes faded, sometimes bright, or more or less altered, of earlier (mostly Greek) examples." Certainly they recognized the existence of a considerable body of scientific knowledge available in Arabic, but it was usually adjudged either as derivative of the Greeks or, at best, the fruit of sheer drudgery (Feingold 1996, p. 445).

A few had "great hopes" to find "most precious stones for the adornment and enriching of my syntaxis mathematike" "in that happy Arabia" (p. 447), and set out to learn Arabic for the purpose. But this was soon followed by a "rapid decline of such studies" (Feingold 1996, p. 448).

Some were simply disillusioned by what they viewed as the small return on their investment. John Greaves, for example, griped ... that the drudgery he had put himself through editing Abulfeda's Geography was simply not worth it: "to speak the truth, those maps, which shall be made out of Abulfeda, will not be so exact, as I did expect; as I have found by comparing some of them with our modern and best charts. In his description of the Red sea, which was not far from him, he is most grossely mistaken; what may we think of places remoter?" (Feingold 1996, p. 448)

Others too lamented "how greate the losse of time was to study much the Eastern languages" and no longer "much care for to trouble myself about the keys [to oriental learning] when there was no treasure of things to be come at" (Feingold 1996, p. 449).

[Francis Bacon agreed:] "The sciences which we possess come for the most part from the Greeks. ... Neither the Arabians nor the schoolmen need be mentioned; who in the intermediate time rather crushed the sciences with a multitude of treatises, than increased their weight" (Feingold 1996, pp. 443-444). 
Thomas Sprat, the official historian of the [Royal] Society, was willing to admit that the Arabs were "men of deep, and subtile Wit," but he also felt it unnecessary to discuss them in surveying the progress of knowledge because their studies "were principally bent, upon expounding Aristotle, and the Greek Physitians." Besides, "they injoy'd not the light long enough. ... It mainly consisted, in understanding the Antients; and what they would have done, when they had been weary of them, we cannot tell" (Feingold 1996, p. 454).

More disparaging was Joseph Glanvill who faulted the Arabs principally for their blind devotion to Aristotle. ... "These Successors of the Greeks did not advance their Learning beyond the imperfect Stature in which it was delievered to them." (Feingold 1996, p. 454)

William Wotton [held that the Arabs] "translated the Grecian Learning into their own Language [but] had very little of their own, which was not taken from those Fountains." ... "There is little to be found amongst them, which any Body might not have understood as well as they, if he had carefully studied the Writings of their Grecian Masters. ... There are vast Quantities of their Astronomical Observations in the Bodleian Library, and yet Mr. Greaves and Dr. Edward Bernard, two very able Jugges, have given the World no Account of any Thing in them, which those Arabian Astronomers did not, or might have not learnt from Ptolemee's Almagest, if we set aside their Observations which their Grecian Masters taught them to make" (Feingold 1996, p. 455).

Theophilus Gale ... [argued that] it is not Aristotle ... who should be blamed for breeding that "Sophistic kind of Disputation, which now reigns in the Scholes." This was the doing of his Arab commentators, Averroes and Avicenna in particular, "who, being wholly unacquainted with the Greek Tongue, were fain to depend upon the versions of Aristotle, which being very imperfect, left them under great darknesse and ignorance touching Aristotle's mind and sense; whence there sprang a world of 
unintelligible Termes and Distinctions, with as many Sophistic Disputes and Controversies. These the Scholemen (more barbarous than the Arabians) greedily picked up ... and incorporated with their Theologie" (Feingold 1996, p. 456).

Remarkably, all of this is quoted from the one article Ragep himself singled out as support for his claim that it would have made little sense for people like Copernicus to think for themselves since they had so much to learn from the much wiser Arabic sources. If there was any meaningful evidence of great respect for late Islamic astronomy in 16th-century Europe one can be sure that Ragep would have loved to cite it. Instead Ragep is forced to resort to citing a source that at length proves the exact opposite of what he claims.

But even if we put this extensive evidence aside, a prima facie puzzle for the transmission believers still remains: If Copernicus had so much respect for Arabic sources and learned so much from them, why does he not cite them? He goes out of his way to cite even obscure Greek sources that can be construed as lending credibility to his theory, yet he cites Arabic sources only for observational data. Why?

Is it because he wanted to claim their discoveries as his own, inflating his own originality? Then why did he make every effort to attribute heliocentrism and the Tusi couple to Greek authors, and clearly give them much more credit than the surviving sources necessitates? (See footnotes 4 and 11.)

Is it because the Tusi couple was already widely known as an Arabic innovation in the Latin West, as Ragep has suggested, so that an attribution would have been superfluous? No. There is no evidence of this and notable evidence to the contrary, as we observed above in Section 3.

Is it because he could not cite works that were not available in Latin and that he perhaps only knew by word of mouth? No, because that didn't stop him from citing very obscure Greek figures from whom nothing survives but the most tenuous allusions. ${ }^{11}$

${ }^{11}$ E.g.: "Philolaus the Pythagorean - no ordinary mathematician, whom Plato's biographers say Plato went to Italy for the sake of seeing - is supposed to have held that the Earth moved in a circle and wandered in some other movements and was one of the planets" (Copernicus 1995, p. 13). 
Is it because of a religious bias? Hardly. The Greeks he cites so eagerly were not Christians either, and he does after all often cite various Islamic authors for their observational data. And of course Christian bias certainly did not stop him from introducing the heretical idea of heliocentrism, even though it is inconsistent with scripture.

Is it because the Islamic authors in question were largely unknown and hence did not lend authority like their Greek counterparts? This would "explain" why Copernicus didn't cite them only at the cost of introducing the must greater problem of how, in that case, he knew about them in the first place.

Or is it because the Islamic authors were known only among experts and not among the vulgar masses, and hence there would be no point in citing them? Again, Copernicus does cite the most obscure Greek sources that were certainly not generally accepted authorities. And his whole work is "written for mathematicians" anyway and has very little regard for other readers. ${ }^{12}$

In sum, if Copernicus really did copy from late Arabic sources, his citation habits are perplexing and inconsistent. Everything he writes is, however, eminently consistent with him holding the standard 17th-century opinion that Arabic works in astronomy were "derivative of the Greeks or, at best, the fruit of sheer drudgery" (Feingold 1996, p. 445).

\section{Conclusion}

In Blåsjö 2014, I sought to address all specific evidence and arguments that had been offered in the literature in support of the thesis that $\mathrm{Co}_{-}$ pernicus was influenced by Maragha astronomy. In the present paper, I have attempted to address all substantial additional points that have been raised to the same end since then. Altogether I have found that there is no convincing evidence that Copernicus knew about and copied any elements of Maragha astronomy, and no compelling reason to think that he did not develop these ideas independently.

\footnotetext{
12 "Idle talkers ... ignorant of mathematics ... worry me so little that I shall ... scorn their judgments." "Mathematics is written for mathematicians" (Copernicus 1995, p. 7).
} 


\section{Bibliography}

Bala, Arun 2016: The Scientific Revolution and the Transmission Problem. Confluence: Online Journal of World Philosophies 4(2016), pp. 62-80. Available online: https://scholarworks.iu.edu/iupjournals/index.php/confluence/article/download/558/63/.

Barker, Peter; Heidarzadeh, Tofigh 2016: Copernicus, the Tusi Couple and EastWest Exchange in the Fifteenth Century. [In:] Miguel A. Granada, Patrick J. Boner \& Dario Tessicini (eds.), Unifying Heaven and Earth: Essays in the History of Early Modern Cosmology. Publicacions i Edicions de la Universitat de Barcelona, 2016, pp. 19-57. Available online: https:// books.google.pl/books?id=uH2bDQAAQBAJ.

Blåsjö, Viktor 2014: A Critique of the Arguments for Maragha Influence on Copernicus. Journal for the History of Astronomy 45(2), pp. 183-195. DOI: $10.1177 / 002182861404500203$.

Blåsjö, Viktor 2015: Some notes on my Copernicus paper. Intellectual Mathematics. October 9, 2015. Available online: http://intellectualmathematics.com/blog/ some-notes-on-my-copernicus-paper/.

Blåsjö, Viktor 2016: Reply to Arun Bala on Copernicus-Maragha issue. Intellectual Mathematics. October 20, 2016. Available online: http://intellectualmathematics.com/blog/reply-to-arun-bala-on-copernicus-maragha-issue/.

Blåsjö, Viktor 2017: On the role of Arabic sources in early modern astronomy. Intellectual Mathematics. July 13, 2017. Available online: http://intellectualmathematics.com/blog/on-the-role-of-arabic-sources-in-early-modern-astronomy/.

Di Bono, Mario 1995: Copernicus, Amico, Fracastoro and Tusi’s Device: Observations on the Use and Transmission of a Model. Journal for the History of Astronomy 26, pp. 133-154. Available online: http://articles.adsabs.harvard.edu/ cgi-bin/nph-iarticle query?1995JHA....26..133D\&amp; data type=PDF HIGH\&amp; whole paper=YES\&amp;type=PRINTER\&amp; filetype=.pdf.

Copernicus, Nicolaus 1995: On the Revolutions of the Heavenly Spheres. Translated by Charles Glenn Wallis. Prometheus Books, Great Minds Series.

Copernic, Nicolas 2015: Des révolutions des orbes célestes. 3 volumes. Critical edition, translation, and introduction by Michel-Pierre Lerner, Alain-Philippe Segonds, and Jean-Pierre Verdet. Paris: Les Belles Lettres.

Curtze, Maximilian 1895: Mathematisch-historische Miscellen. Bibliotheca Mathematica 9(2), pp. 33-42.

Dobrzycki, Jerzy; Rosen, Edward 1978: Nicholas Copernicus on the Revolutions. Volume 2, Macmillan, 1978. 
Droppers, Garrett 1966: The Questiones de spera of Nicole Oresme. Ph.D. Dissertation. University of Wisconsin.

Feingold, Mordechai 1996: Decline and Fall: Arabic Science in Seventeenth-Century England. [In:] F. Jamil Ragep, Sally P. Ragep, Steven John Livesey (eds.), Tradition, Transmission, Transformation: Proceedings of Two Conferences on Pre-Modern Science Held at the University of Oklahoma. Leiden: Brill, 1996, pp. 441-469. Available online: https://books.google.nl/books?id=Kl1COWj9ubAC\&print$\underline{\mathrm{sec}}=$ frontcover $_{\mathrm{v}}={ }_{\text {onepage } \& \mathrm{q} \& \mathrm{f}=\text { false. }}$.

Goddu, André 2010: Copernicus and the Aristotelian Tradition: Education, Reading, and Philosophy in Copernicus's Path to Heliocentrism. Leiden (Netherlands), Boston (USA): Brill.

Hartner, Willy 1971: Trepidation and Planetary Theories: Common Features in Late Islamic and Early Renaissance Astronomy. Convegno internazionale, 9-15 Aprile 1969: Tema: Oriente et occidentenel medioevo: filosofia e scienze. Accademia Nazionale dei lincei, Fondazione Alessandro Volta, 1971, pp. 609-632.

Kokowski, Michał 2004: Copernicus's Originality: Towards Integration of Contemporary Copernican Studies, Warsaw - Cracow: Instytut Historii Nauki PAN.

Kren, Claudia 1971: The Rolling Device of Nasir al-Din al-Tusi in the De spera of Nicole Oresme? Isis 62(4), pp. 490-498.

Nobis, Heribert; Pastori, Anna Maria 2002: Receptio Copernicana: Texte zur Aufnahme $\operatorname{der}$ Copernicanischen Theorie. Berlin, München, Boston: De Gruyter Oldenburg.

Nobis, Heribert; Sticker, Bernhard 1984: De revolutionibus libri sex: Neue synoptisch-kritische Ausgabe des lateinischen Textes der Editio prima und des Autographs. Walter de Gruyter.

Ragep, F. Jamil 2017: From Tun to Torun: The Twists and Turns of the Tusi-Couple [In:] Rivka Feldhat \& F. Jamil Ragep (eds.), Before Copernicus: The Cultures and Contexts of Scientific Learning in the Fifteenth Century. Montreal, Quebec, Canada: McGill-Queens's University Press, pp. 161-197.

Rosen, Edward 1939: Three Copernican Treatises: The "Commentariolus" of Copernicus, the "Letter against Werner", the "Narratio prima" of Rheticus. Translated with Introduction and Notes by Edward Rosen. [Records of Civilization, Sources and Studies, Austin P. Evans, Editor.] New York: Columbia University Press.

Saliba, George 1994: A Sixteenth-Century Arabic Critique of Ptolemaic Astronomy: The Work of Shams al-Din al-Khafri, Journal for the History of Astronomy 25, pp. 15-38. Available online: http://articles.adsabs.harvard.edu/cgi-bin/nph-iarticle query?1994JHA....25...15S\&amp; data type=PDF HIGH\&amp; whole paper=YES\&amp;type $=$ PRINTER\&amp; filetype $=$.pdf.

Saliba, George 2007: Islamic science and the making of the European Renaissance, MIT Press. 
Swerdlow, Noel M. 1973: The derivation and first draft of Copernicus's planetary theory: A translation of the Commentariolus with commentary, Proceedings of the American Philosophical Society 117, pp. 423-512.

Swerdlow, N. M. 2017: Copernicus's Derivation of the Heliocentric Theory from Regiomontanus's Eccentric Models of the Second Inequality of the Superior and Inferior Planets, Journal for the History of Astronomy 48(1), pp. 33-61.

Toomer, G. J. 1988: Ptolemy's Almagest. Princeton, New Jersey, USA: Princeton University Press. Translated and annotated by G.J. Toomer. With a foreword by Owen Gingerich.

Veselovsky, I. N. 1973: Copernicus and Nasir al-Din al-Tusi. Journal for the History of Astronomy 4, pp. 128-130. Available online: http://articles.adsabs.harvard. edu/cgi-bin/nph-iarticle query?1973JHA.....4..128V\&amp; data type=PDF HIGH\&amp; whole paper=YES\&amp;type=PRINTER\&amp; filetype $=$.pdf. 